\title{
SISTEM PENDUKUNG PENGAMBILAN KEPUTUSAN MENGGUNAKAN METODE SIMPLE ADDITIVE WEIGHTING (SAW) GUNA MENENTUKAN PRODUK UNGGULAN DI KABUPATEN GUNUNGKIDUL
}

\author{
Fajar Budi Hartono ${ }^{1}$, Hendro Joko Prasetyo ${ }^{2}$ \\ Teknik Informatika, Fakultas Ilmu Komputer, Universitas Widya Dharma Klaten \\ Jl. Ki Hajar Dewantara, Klaten 57438 \\ Tlp. 0272-322363,Faks. 0272-323288 \\ Majesty.fayen17@gmail.com, hendromkom@yahoo.co.id
}

\begin{abstract}
Gunungkidul has sufficient natural resources and human resources. Various industrial sectors in the Regency include mining, agriculture, plantations, crafts and fisheries. The potential has not all been able to develop according to expectations because local governments have not been able to determine the leading industrial sector. The government needs a system that can help determine the superior industrial sector. The method used is the Simple Additive Weighting (SAW) Method. This method is able to provide alternative choices by comparing one criterion with other criteria, by first giving weights to each criterion. The test results of the system that has been built determine the order of products that are used as a reference to increase revenue in the industrial sector. This result will determine the order of products that need to be studied and improved because they have been automatically selected by the system.
\end{abstract}

Keyword : kriteria, alternatif, Simple Additive Weighting (SAW)

\section{PENDAHULUAN}

Menyadari bahwa sektor pendapatan daerah sangat penting, negara sangat mendukung setiap warga negaranya untuk meraih kesejahteraan sebaikbaiknya. Beberapa di antaranya melakukan program pelatihan keterampilan kerja. Program ini dapat dikatakan sebagai pelatihan untuk menghasilkan berbagai produk dan menggali potensi daerah sehingga meningkatkan pendapatan masyarakat. Kegiatan ini pendanaannya diberikan oleh pemerintah. Hasil produk usaha yang ada saat ini akan diseleksi sesuai dengan ktiteria yang telah ditentukan, sehingga menghasilkan produk unggulan dari beberapa poduk yang ada di masyarakat

Demikian halnya dengan Kabupaten Gunungkidul yang terdiri dari 18 kecamatan memiliki sektor produk unggulan yang layak untuk diunggulkan yang mampu meningkatkan kesejakteraan masyarakat. Produk unggulan saat ini diantaranya kerajinan, pertambangan, perkebunan, perikanan, pertanian.

Pertanian yang dimiliki kabupaten Gunung Kidul sebagian besar adalah lahan kering tadah hujan, sumber daya alam tambang yang masuk golongan c berupa batu kapur dan batu apung, kalsit, zeolit, bentonit, tras, kaolin dan pasir kwarsa.

Potensi Industri Kerajinan di Kabupaten Gunungkidul diantaranya adalah Kerajinan Kertas Daur Ulang, Kerajinan Kayu, Kerajinan Bambu, Kerajinan Batu Ornamen, Kerajinan Akar Wangi, Kerajinan Perak dan lain-lain.

Produk unggulan harus mampu meningkatkan kesejahteraan masyarakat Gunungkidul di tengah persaingan beberapa produk lokal maupun asing. Untuk menghasilkan produk unggulan ini ada beberapa kriteria yang dibutuhkan sehingga dalam hasil akhir akan muncul urutan produk yang diunggulkan.

Penentuan produk unggulan di Kabupaten Gunungkidul pada proses penentuannnya belum menggunakan komputer aplikasi sistem pendukung pengambilan keputusan. Selama ini pemerintah daerah baru dalam taraf peningkatan keterampilan masyarakat untuk meningkatkan produksi tanpa mempertimbangkan produk yang akan diunggulkan.

Dengan adanya sistem pengambilan keputusan ini diharapkan dapat mempermudah pihak pemerintah daerah dalam hal menentukan produk unggulan yang harus ditingkatkan.

Berdasarkan latar belakang di atas maka rumusan masalahnya adalah, bagaimana menyediakan sistem informasi yang memudahkan pemerintah daerah Kabupaten Gunungkidul dalam menentukan produk unggulan sektor industri dan bagaimana menentukan urutan produk unggulan agar dapat dipakai oleh pemerintah Kabupaten Gunungkidul ?

Tujuan yang akan dicapai yaitu membantu pemerintah daerah menentukan produk unggulan khususnya pemerintah daerah Kabupaten Gunungkidul dan memudahkan masyarakat mendapatkan informasi produk unggulan daerah.

\section{a. Sistem Pendukung Keputusan}

Sistem pendukung keputusan mengandung pengertian yang luas, menurut definisi sistem pendukung keputusan dari berbagai sudut pandang antara lain :

1. Sistem Pendukung Keputusan merupakan suatu sistem interaktif yang mendukung keputusan dalam proses pengambilan keputusan melalui 
alternatif-alternatif yang diperoleh dari hasil pengolahan data, informasi dan rancangan model. (Saripudin, 2009)

2. Menurut Keen dan Scoot Morton Sistem Pendukung Keputusan merupakan penggabungan sumber-sumber kecerdasan individu dengan kemampuan komponen untuk memperbaiki kualitas keputusan. Sistem Pendukung Keputusan juga merupakan sistem informasi berbasis komputer untuk manajemen pengambilan keputusan yang menangani masalah-masalah semi struktur.

b. Karakteristik Sistem Pendukung Keputusan Dari pengertian Sistem Pendukung Keputusan

maka dapat ditentukan karakteristik antara lain :

1. Mendukung proses pengambilan keputusan, menitikberatkan pada management by perception.

2. Adanya interface manusia atau mesin dimana manusia (user) tetap memegang control proses pengambilan keputusan.

3. Mendukung pengambilan keputusan untuk membahas masalah terstruktur, semi terstruktur dan tak struktur.

4. Memiliki kapasitas dialog untuk memperoleh informasi sesuai dengan kebutuhan.

5. Memiliki subsistem-subsistem yang terintegrasi sedemikian rupa sehingga dapat berfungsi sebagai kesatuan item.

6. Membutuhkan struktur data komprehensif yang dapat melayani kebutuhan informasi seluruh tingkatan manajemen.

c. Multi-Attribut Decision Making (MADM) Multiple Attribute Decision Making (MADM) adalah suatu model yang digunakan untuk mencari alternatif optimal dari sejumlah alternatif dengan kriteria tertentu. Inti dari MADM adalah menentukan nilai bobot untuk setiap atribut, kemudian dilanjutkan dengan proses perankingan yang akan menyeleksi alternatif yang sudah diberikan (Pramudyo dan Purnomo,2012). Ada beberapa metode yang dapat digunakan untuk menyelesaikan masalah MADM antara lain (Kusumadewi dkk, 2006) :

1. Simple Additive Weighting Method (SAW)

2. Weighted Product (WP)

3. ELECTRE

4. Technique for Order Preference by Similarity to Ideal Solution (TOPSIS)

5. Analytic Hierarchy Process (AHP)

Dengan mempertimbangkan kelebihan dan kekurangan dari beberapa metode tersebut, penulis memutuskan memilih metode Simple Additive Weighting (SAW) sebagai metode yang sesuai.

Metode SAW sering juga dikenal dengan istilah metode penjumlahan terbobot. Konsep dasar dari metode SAW adalah mencari penjumlahan terbobot dari rating kinerja pada setiap alternatif pada semua atribut. Metode SAW membutuhkan proses normalisasi matriks keputusan (X) ke suatu skala yang dapat diperbandingkan dengan semua rating alternatif yang ada (Kusumadewi, 2006).

Menurut Darmastuti (2013), kelebihan dari model SAW terletak pada kemampuannya untuk melakukan penilaian secara lebih tepat karena didasarkan pada nilai kriteria dan bobot prefensi yang sudah ditentukan. Selain itu, dalam metode SAW terdapat perhitungan normalisasi matriks sesuai dengan nilai atribut benefit dan cost (Afifah, 2012). Menurut Idris (2012), penentuan nilai prioritas vektor bobot dilakukan sesuai kebijakan manajer memberikan nilai vektor bobot secara langsung. Adapun langkah langkahnya adalah sebagai berikut :

a. Menentukan kriteria - kriteria yang akan dijadikan acuan dalam pengambilan keputusan, yaitu $\mathrm{Ci}$.

b. Menentukan rating kecocokan setiap alternatif pada setiap kriteria.

c. Membuat matriks keputusan berdasarkan kriteria (Ci), kemudian melakukan normalisasi matriks berdasarkan persamaan yang disesuaikan dengan jenis atribut (atribut keuntungan atau biaya) sehingga diperoleh matriks ternormalisasi R. Formula untuk melakukan normalisasi tersebut adalah sebagai berikut :

$$
r_{i j}=\left\{\begin{array}{cl}
\frac{X_{i j}}{\operatorname{Max}_{i j}} & \begin{array}{l}
\text { Jika j adalah atribut } \\
\text { keuntungan (benefit) }
\end{array} \\
\frac{\operatorname{MinX}_{i j}}{X_{i j}} & \begin{array}{l}
\text { Jika j atribut adalah } \\
(\text { cost })
\end{array}
\end{array}\right.
$$

Keterangan :

$\mathrm{R}_{\mathrm{ij}} \quad$ : Rating kinerja ternormalisasi

$\operatorname{Max}_{\mathrm{i}}$ : Nilai maksimum dari setiap alternatif dan kriteria

$\operatorname{Min}_{\mathrm{i}}$ : Nilai minimum dari setiap alternatif dan kriteria

$\mathrm{X}_{\mathrm{ij}}$ : Alternatif dan kriteria dari matriks.

d. Hasil akhir diperoleh dari setiap proses perankingan yaitu penjumlahan dari perkalian matriks ternormalisasi $\mathrm{R}$ dengan vector bobot (w) sehingga diperoleh nilai terbesar yang dipilih sebagai alternatif terbaik (Vi) sebagai solusi.

$$
V_{i}=\sum_{j=1}^{n} w_{j} r_{i j}
$$

Keterangan :

$\mathrm{V}_{\mathrm{i}}$ : Nilai akhir dari alternatif

$\mathrm{W}_{\mathrm{j}}$ : Bobot yang telah ditentukan

$\mathrm{r}_{\mathrm{ij}}$ : Normalisasi matriks 


\section{METODE}

Metode yang dipakai yaitu Metode SAW sering juga dikenal dengan istilah metode penjumlahan terbobot. Konsep dasar dari metode SAW adalah mencari penjumlahan terbobot dari rating kinerja pada setiap alternatif pada semua atribut. Metode SAW membutuhkan proses normalisasi matriks keputusan (X) ke suatu skala yang dapat diperbandingkan dengan semua rating alternatif yang ada.

Kelebihan dari model SAW terletak pada kemampuannya untuk melakukan penilaian secara lebih tepat karena didasarkan pada nilai kriteria dan bobot prefensi yang sudah ditentukan. Selain itu, dalam metode SAW terdapat perhitungan normalisasi matriks sesuai dengan nilai atribut benefit dan cost.

\section{PEMBAHASAN}

Penelitian ini menghasilkan sebuah sistem berbasis dekstop untuk seleksi produk unggulan guna menentukan produk yang layak untuk mendapatkan nominasi unggulan yang pada gilirannya akan memberikan masukan kepada pengambil keputusan dalam hal ini pimpinan Pemerintah Daerah di Kabupaten Gunungkidul. Sistem tersebut membantu proses pengambilan keputusan dengan melakukan proses penentuan alternatif terpilih dengan menggunakan metode Simple Additive Weighting. Sistem menggunakan elemen produk yang dapat diunggulkan sebagai alternatif dan elemen kriteria produk sebagai kriteria pada pengambilan keputusan dengan $S A W$. Hasil pengolahan data berupa alternatif terpilih untuk produk unggulan daerah.

Untuk menyelesaikan permasalahan tersebut, pihak kantor perindustrian dan perdagangan Kabupaten Gunungkidul memerlukan suatu system informasi pendukung keputusan dalam pemilihan produk unggulan. Dengan adanya sisitem ini, diharapkan dapat membantu manajemen kantor perindustrian memnuhi kebutuhan informasi yang diperlukan oleh pemerintah daerah.

Alternatif jenis industri meliputi : Kerajinan, perkebunan, pertanian, pertambangan dan perikanan.

Masing-masing alternatif tersebut kemudian diberi kode yaitu, A1: kerajinan, A2:perkebunan, A3:pertanian, A4:pertambangan dan A5:perikanan.

Alternatif jenis industri yang ada sebenanya lebih dari 5 jenis, tetapi karena ke lima jenis inilah yang sedang digalakkan pemerintah Kabuptaen Gunungkidul untuk penerimaan daerah dan peningktan kesejahteramaan masyarakat maka dipilihlah ke lima jenis alternatif tersebut.

Kriteria jenis industri yang meliputi : jumlah unit usaha(unit), jumlah tenaga kerja(orang), nilai produksi (juta rupiah), nilai investasi(juta rupiah), nilai kompetitif (0-9).

Masing-masing kriteria tersebut kemudian diberi kode yaitu, $\mathrm{C} 1=$ jumlah unit usaha(unit), $\mathrm{C} 2=$ nilai produksi (juta rupiah), C3= nilai kompetitif (0-9), $\mathrm{C} 4=$ nilai investasi(juta rupiah), $\mathrm{C} 5=$ jumlah tenaga kerja(orang).

Tabel 1. Nilai Kriteria Untuk Masing-masing Alternatif

\begin{tabular}{|c|c|c|c|c|c|}
\hline \multirow{2}{*}{$\begin{array}{c}\text { Alter } \\
\text { natif }\end{array}$} & \multicolumn{5}{|c|}{ Kriteria } \\
\cline { 2 - 6 } & C1 & C2 & C3 & C4 & C5 \\
\cline { 2 - 6 } A1 & 25 & 7.000 & 7 & 7.500 & 3204 \\
\hline A2 & 24 & 6.000 & 9 & 5.000 & 3632 \\
\hline A3 & 28 & 5.000 & 4 & 1.500 & 1150 \\
\hline A4 & 20 & 8.000 & 9 & 6.000 & 1242 \\
\hline A5 & 30 & 4.500 & 7 & 1.100 & 2340 \\
\hline
\end{tabular}

Nilai yang terdapat pada Tabel 4.1 tersebut merupakan nilai rata-rata selama kurun waktu 3 tahun terakhir berdasarkan laporan yang telah disusun oleh Disperindak dalam rangka untuk evaluasi peningkatan kesejahteraan masyarakat.

\subsection{Tahap-tahap Penyelesaian Penyeleksian Alternatif}

\section{Tahap 1}

Terdapat 2 kategori yang membedakan kriteraikriteria pada Tabel 4.2 diatas antara lain :

1. Kriteria C1 (Jumlah unit usaha), C2 (Nilai Produksi) dan C3 (Nilai Kompetitif)) dan C4 (Nilai Investasi) adalah kriteria benefit;

2. Kriteria C5 (Jumlah Tenaga Kerja) adalah kriteria cost (biaya)

Tahap 2

Sebelumnya dilakukan perbaikan bobot terlebih dahulu, sehingga total bobot $\Sigma w j=1$ dengan cara menggunakan persamaan (1).

$W_{j}=\frac{w_{j}}{\sum w j}$

Sehingga mendapatkan hasil seperti pada Tabel 2 seperti di bawah ini.

\section{Tabel 2. Tabel Bobot Antar Kriteria}

Pembobotan dari setiap kriteria dari perhitungan tersebut seperti pada Tabel 4.3 di bawah ini :

\begin{tabular}{|l|l|}
\hline Pembobotan antar kriteria & \\
\hline Kriteria Benefit & 0.23 \\
\hline C1 (Jumlah unit usaha (unit)) & 0.32 \\
\hline C2 (Nilai produksi (juta rupiah)) & 0.2 \\
\hline C3 (Nilai kompetitif (0-9)) & 0.15 \\
\hline C4 (Nilai Investasi (juta rupiah)) & 0 \\
\hline Kriteria Cost & 0.1 \\
\hline C5 (Jumlah tenaga kerja (orang)) & \\
\hline
\end{tabular}


Tabel 3. Pembobotan Setiap Kriteria

\begin{tabular}{|c|c|c|}
\hline \multirow{2}{*}{\multicolumn{3}{|c|}{ A }} \\
\hline & & Bobot \\
\hline & $>30$ & 1 \\
\hline & $20-29$ & 0.75 \\
\hline & $10--19$ & 0.5 \\
\hline & $1--9$ & 0.25 \\
\hline \multicolumn{3}{|l|}{$\mathrm{C} 2$} \\
\hline & $9.000 .000 .000--10.000 .000 .000$ & 1 \\
\hline & 7.000.000.000-8.900.000.000 & 0.75 \\
\hline & $5.000 .000 .000-6.900 .000 .000$ & 0.5 \\
\hline & 1.000.000.000-4.9000.000.000 & 0.25 \\
\hline \multicolumn{3}{|l|}{$\mathrm{C} 3$} \\
\hline & 9 & 1 \\
\hline & $7--8$ & 0.75 \\
\hline & $5--6$ & 0.5 \\
\hline & $4-1$ & 0.25 \\
\hline \multicolumn{3}{|l|}{$\mathrm{C} 4$} \\
\hline & $>7.500 .000 .000$ & 1 \\
\hline & $5.000 .000 .000--7.400 .000 .000$ & 0.75 \\
\hline & $3.500 .000 .000--4.900 .000 .000$ & 0.5 \\
\hline & $<3.500 .000 .000$ & 0.25 \\
\hline \multicolumn{3}{|l|}{$\mathrm{C} 5$} \\
\hline & $<1500$ & 1 \\
\hline & $1500--2500$ & 0.75 \\
\hline & $2501--3500$ & 0.5 \\
\hline & $>3500$ & 0.25 \\
\hline
\end{tabular}

Sehingga didapatkan tabel bobot kriteria dari masing-masing alternatif seperti pada Tabel 4 di bawah ini :

\section{Tabel 4. Bobot Kriteria}

\begin{tabular}{|l|l|l|l|l|l|}
\hline \multirow{2}{*}{ Alternatif } & \multicolumn{4}{l|}{ Kriteria } & \multicolumn{4}{l|}{} \\
\cline { 2 - 6 } & 1 & 2 & 3 & 4 & 5 \\
\hline A1 & 0.75 & 0.75 & 0.75 & 1.00 & 0.5 \\
\hline A2 & 0.75 & 0.50 & 1 & 0.75 & 0.25 \\
\hline A3 & 0.75 & 0.50 & 0.25 & 0.25 & 1 \\
\hline A4 & 0.75 & 0.75 & 1 & 0.75 & 1 \\
\hline A5 & 1 & 0.25 & 0.75 & 0.25 & 0.75 \\
\hline
\end{tabular}

\section{Tahap 3}

Menentukan Nilai Vektor S, yang dapat dihitung dengan menggunakan formula berikut :
Dari kriteria yang telah disebutkan di atas bahwa ada 2 kriteria yaitu kriteria benefit dan kriteria cost, sehingga perlu dinormalisasi sesuai dengan kriteria tersebut.

1. Normalisasi kriteria benefit

$\mathrm{R}_{\mathrm{ii}}=\left(\mathrm{X}_{\mathrm{ij}} / \max \left\{\mathrm{X}_{\mathrm{ij}}\right\}\right)$

Pada baris R1, Masing-masing kriteria memiliki nilai sebagai berikut:

Tabel 4. Normalisasi Kriteria Benefit

\begin{tabular}{|l|l|l|l|}
\hline \multicolumn{1}{|c|}{$\mathrm{C} 1$} & \multicolumn{1}{|c|}{$\mathrm{C} 2$} & \multicolumn{1}{c|}{$\mathrm{C} 3$} & \multicolumn{1}{c|}{$\mathrm{C} 4$} \\
\hline 0.75 & 1.00 & 0.75 & 1.00 \\
\hline 0.75 & 0.67 & 1.00 & 0.75 \\
\hline 0.75 & 0.67 & 0.25 & 0.25 \\
\hline 0.75 & 1.00 & 1.00 & 0.75 \\
\hline 1.00 & 0.33 & 0.75 & 0.25 \\
\hline
\end{tabular}

2. Normalisasi kriteria cost

$\mathrm{R}_{\mathrm{ii}}=\left(\min \left\{\mathrm{X}_{\mathrm{ij}}\right\} / \mathrm{X}_{\mathrm{ij}}\right)$

Pada baris R1, Masing-masing kriteria memiliki nilai sebagai berikut:

Tabel 5. Normalisasi Kriteria Cost

\begin{tabular}{|l|}
\hline C5 \\
\hline 0.5 \\
\hline 1.00 \\
\hline 0.25 \\
\hline 0.25 \\
\hline 0.333333 \\
\hline
\end{tabular}

Sehingga menghasilkan table normalisasi dari ke dua kriteria tersebut, pada table 6 di bawah ini.

Tabel 6. Normalisasi Kriteria Benefit dan Cost

\begin{tabular}{|l|l|l|l|l|l|}
\hline \multirow{2}{*}{ Alternatif } & \multicolumn{4}{|l}{ Kriteria } & \multicolumn{4}{l|}{} \\
\cline { 2 - 6 } & $\mathrm{C} 1$ & $\mathrm{C} 2$ & $\mathrm{C} 3$ & $\mathrm{C} 4$ & $\mathrm{C} 5$ \\
\hline A1 & 0.75 & 1.00 & 0.75 & 1.00 & 0.50 \\
\hline A2 & 0.75 & 0.67 & 1.00 & 0.75 & 1.00 \\
\hline A3 & 0.75 & 0.67 & 0.25 & 0.25 & 0.25 \\
\hline A4 & 0.75 & 1.00 & 1.00 & 0.75 & 0.25 \\
\hline A5 & 1.00 & 0.33 & 0.75 & 0.25 & 0.33 \\
\hline
\end{tabular}

$S_{1}=\prod_{J=1}^{n} X_{i j w_{j}}$ 


\section{Tahap 4}

Menentukan nilai vector yang akan digunakan menghitung Preferensi (Vi) untuk perengkingan. Formulanya seperti berikut:

$$
V_{i}=\sum_{j=1}^{n} w_{j} r_{i j}
$$

Sehingga setelah diolah menghasilka tabel di bawah ini.

Tabel 7 Hasil Perengkingan Alternatif

\begin{tabular}{|l|c|c|}
\hline Alternatif & Kode & Nilai \\
\hline Kerajinan & A1 & 0.8200 \\
\hline Pertambangan & A4 & 0.8075 \\
\hline Perkebunan & A2 & 0.8066 \\
\hline Perikanan & A5 & 0.6164 \\
\hline Pertanian & A3 & 0.5066 \\
\hline
\end{tabular}

Tabel 7 memberikan hasil bahwa dari ke lima alternatif tersebut muncul urutan produk unggulan yang dapat dipakai untuk mendukung pengambilan keputusan, produk yang akan diunggulkan. Hal ini untuk lebih meningkatkan pendapatan daerah maupun meningkatkan taraf perekonomian rakyat khususnya di Kabupaten Gunungkidul.

Adapun urutan produk unggulan dari perhitungan tersebut adalah, A1 =Kerajinan (0.8200), A4=Pertambangan (0.8075), A2=Perkebunan (0.8066), A5=Perikanan (0.6164) dan A3=Pertanian $(0.5066)$

\subsection{Proses penyeleksian menggunakan aplikasi yang telah dibangun menggunakan metode SAW}

3.2.1 Memasukan alternatif dan kriteria yang telah ditentukan

Langkah pertama yang dilakukan adalah memasukkan alternatif dilanjutkan dengan memasukkan kriteria yang telah ditentukan.

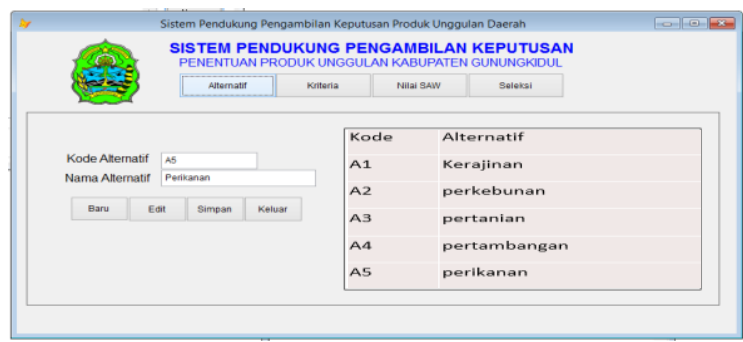

Gambar 1. Interface Form Pengisian Alternatif

Ke lima alteratif yaitu, A1:kerajinan, A2:perkebunan, A3:pertanian, A4:pertambangan, A5:perikanan di masukkan dalam form tersebut, kemudian dilanjutkan dengan memasukkan ke lima kriteria yaitu, $\mathrm{C} 1=$ jumlah unit usaha(unit), $\mathrm{C} 2=$ nilai produksi (juta rupiah), C3= nilai kompetitif (0-9), $\mathrm{C} 4=$ nilai investasi(juta rupiah), $\mathrm{C} 5=$ jumlah tenaga kerja(orang).

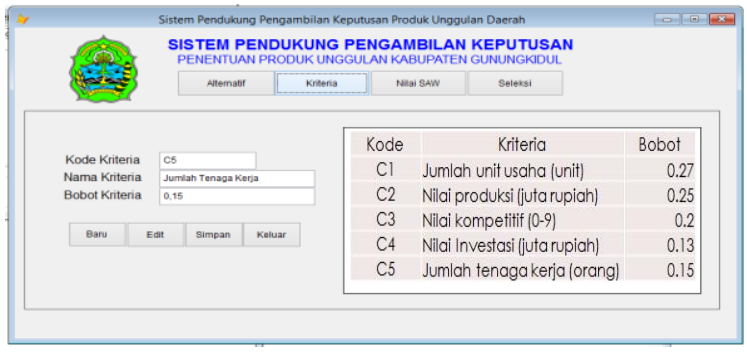

Gambar 2. Interface Form Pengisian Kriteria

\subsubsection{Memasukkan nilai kriteria dan vektor bobot setiap kriteria}

Langkah ini dilakukan untuk mengisi nilai setiap kriteria sesuai dengan yang telah dimasukkan seperti pada gambar 1 pada bagian sub menu Nilai SAW dan mengisi vektor bobot setiap kriteria, sehingga hasilnya seperti gambar di bawah ini.

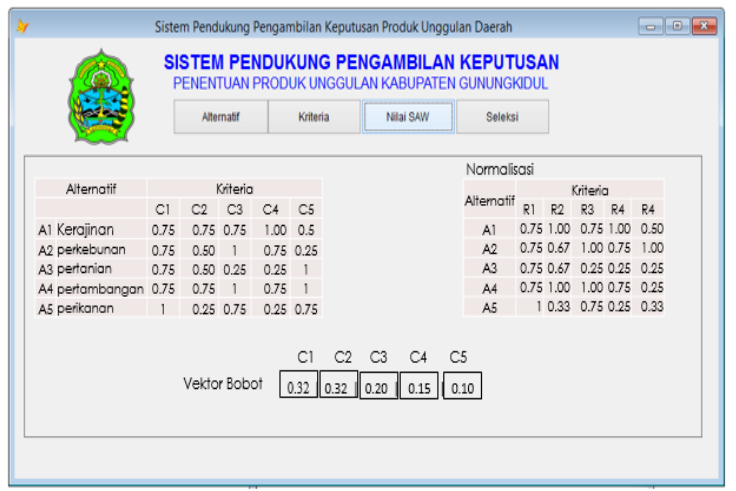

Gambar 3. Interface form pengisian kriteria dan vektor bobot

\subsubsection{Proses Seleksi Alternatif}

Proses ini dilakukan untuk menyeleksi alternatif secara otomatis dengan melakukan klik pada sub menu Seleksi, sehingga hasilnya sepeti pada gambar di bawah ini.

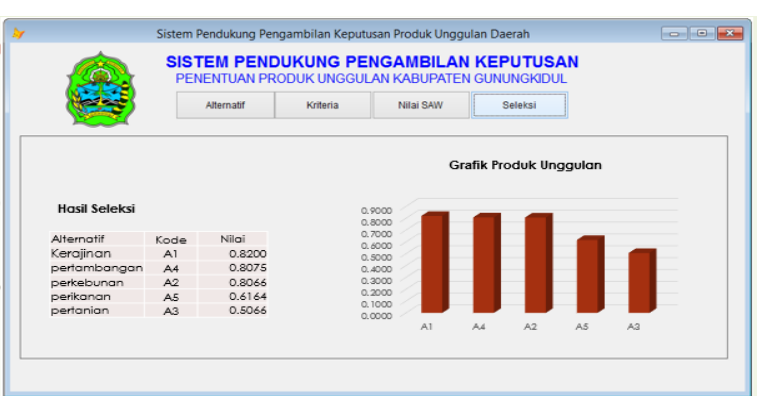

\section{Gambar 4. Proses Seleksi Alternatif}

Urutan hasil seleksi dari sistem aplikasi merupakan urutan prioritas produk unggulan yang dapat dipakai untuk mendukung pengambilan keputusan memilih produk unggulan. 


\section{KESIMPULAN}

Dari penelitian yang telah dilakukan, diperoleh beberapa kesimpulan, yaitu :

1. Membangun aplikasi perangkat lunak yang dimodelkan dengan SAW, sehingga membantu pengambil keputusan untuk mengambil keputusan memilih produk unggulan daerah Kabupaten Gunungkidul.

2. Penggunaan aplikasi ini dapat secara otomatis mengurutkan produk unggulan.

Urutan produk unggulan :
a. Kerajinan
$=0.8200$
b. Pertambangan
$=0.8075$
c. Perkebunan
$=0.8066$
d. Perikanan
$=0.6164$
e. Pertanian
$=0.5066$

\section{PUSTAKA}

Idris, Sri Ani Lestari. 2012. Analisis Perbandingan Metode Analytical Hierarchy Process (AHP) dan Simple Additive Weighting (SAW). (http://ti.fatek.ung.ac.id/down.php?file=sri_ani_1 estari_idris.pdf), diakses 4 Maret 2015

Kendall,E., dan Julie, E., 2003. Analisis dan Desain Perancangan Sistem). Jakarta: Prenhilliando

Jogiyanto. 2005. Analisis Dan Desain Sistem Informasi. Yogyakarta: Andi

Kristanto, Harianto.1994. Konsep dan Perancangan Database. Yogyakarta : Andi

Kusumadewi, Sri., Hartati, S., Harjoko, A., Wardoyo, R. 2006. Fuzzy Multi-Atribute Decision Making. Yogyakarta: Graha Ilmu

Pohan, Husni Iskandar, Kusnassriyanto Syaiful Bahri. 1997. Pengantar Perancangan Sistem. Jakarta: Erlangga

Subakti, Irfan. 2010. Sistem Penunjang Keputusan (Decision Support System). Fakultas Teknologi Informasi. Institut Teknologi Sepuluh November. Surabaya.(Online),

(http://directory.umm.ac.id/tik/Buku_Panduan_ SPK.pdf), diakses 01 Januari 2014

Saripudin, 2009. Sistem Pendukung Keputusan. (http://file.upi.edu/Direktori/FPIPS/PRODI._MA NAJ._PEMASARAN_WISATA/132320795\%20 $\% 20$ saripudin/Sistem\%20Informasi\%20Manajem en\%20Pemasaran\%20Pariwisata/Lecture_12_Sis tem_Pendukung_Keputusan_Pert_12.pdf), diakses pada tanggal 14 Januari 2014

Suyantoro, Sigit. 2007. Pemrograman Database dengan Visual Foxpro 9.0. Semarang:Andi

Yasin, Verdi. 2012. Rekayasa Perangkat Lunak Berorientasi Objek. Jakarta : Mitra Wacana Media (http://mjeducation.com/bsm-beasiswapendidikan-bagi-siswa-kurang-mampu/ ) diakses pada tanggal 11 Maret 2015

Sutarman, 2009. Pengantar Teknologi Informasi. Jakarta : Andi 